\title{
Educações da visão: estratégias relacionais na cultura visual
}

\section{Resumo}

Este artigo está organizado em três partes. Através de exemplos do século XX na educação das artes visuais na Escandinávia, a primeira parte, "Indagações Epistemológicas", discute como a construção histórica e social de estratégias modernas dominantes de visão ocorreram. A segunda parte, "Redescrições Experimentalistas", utiliza o pensamento pós-estruturalista feminista sobre cultura visual numa tentativa de explorar compreensões alternativas de cultura visual. Na terceira parte, "Educações da Visão na Modernidade Tardia", socialização e auto criação são propostas como duas funções educacionais diferentes, mas, suplementares, nas quais a educação visual contemporânea inspirada em abordagens epistemológicas e experimentalistas buscaria cumprir essa meta.

Palavras-chave:

Indagações epistemológicas, redescrições experimentalistas, educação da cultura visual 


\title{
Educations of vision: relational strategies in visual culture
}

\author{
HELENE ILLERIS
}

\begin{abstract}
The article is divided into three parts. Through examples from twentieth century Scandinavian visual arts education the first part "Epistemological inquiries", discusses how the historical and social construction of dominant modem strategies of vision has occurred. The second part "Experimentalist redescriptions" employs poststructuralist and feminist thinking about visual culture in an attempt to explore alternative understandings of visual education. In the third part "Educations of vision in late modernity" socialization and self creation are proposed as two different, but supplementary, educational functions which contemporary visual education inspired by epistemological and experimentalist approaches should aim to fulfill.
\end{abstract}

Keywords: Epistemological inquires, experimentalist redescriptions, visual culture education 
$M_{\text {y approach to visual culture in education in this article will }}$ be of a philosophical nature. This means that I will try to develop and discuss some issues which touch upon questions about basic relations between human beings and the world. I have chosen this approach because I am interested in how some of the questions concerning vision and visuality ${ }^{1}$, which have been raised in visual culture studies, are relevant in discussions concerning educational issues in late modernity. It would be beyond the scope of this article to try to explore all the facets of this complex issue. I have therefore chosen to build up my article as a number of introductory frames in an attempt to outline some areas of investigation which I will try to explore and develop in my future research on visual culture in education.

My most important theoretical framing comes from the loosely organized and transdisciplinary area of inquiry called visual culture studies. In visual culture studies I have found that the dominant approaches can be loosely divided into two groups. I call the first group of approaches epistemological and the second group experimentalist. Epistemological approaches to visual culture aim at destabilizing and denaturalizing inherited categories and understandings of visuality and demonstrate how these understandings depend on historically and socially contingent constructions. The inquiries into the genealogy of Western models of vision by the American scholars Martin Jay (1993) and Jonathan Crary (1990), whose texts I use in the first part of this article, are among the most well-known examples of this analytical strategy. Experimentalist approaches attempt to invent and elaborate alternative analytical and representative tools and redescriptions. These approaches aim at helping scholars and students of visual culture to create new images and vocabularies concerning vision and visual events. The experimentalist redescriptions in the second part of this 
article are inspired by scholars like Mieke Bal and Norman Bryson (1991) and Irit Rogoff $(1998,2000)$. In their work you find the employment of new forms of inquiry into visuality like visual events and the curious eye which can be seen as challenges to traditional Western models of vision. In the third and fourth part of this article I will relate the epistemological inquiries and experimental redescriptions from the first two parts to what I propose as the most important educational goals in late modern societies: socialization and self creation.

My field of inquiry will be Scandinavian visual arts education. The reasons for this choice are firstly that visual arts education is the educational field which is traditionally considered to be most engaged in questions of visuality, and secondly that my professional background is in this field. In my recent dissertation Billede, predagogik og magt (Picture, Pedagogy, and Power; ILLERIS, 2002a) I discuss how shifting discourses about seeing and the education of vision have been central to the construction of the categories of the good child and the good picture in Scandinavian art education. I elaborate on some of these analyses in the first part of this article by presenting three strategies of vision which have been crucial in art education in the past century.

\section{Part I: Epistemological inquiries}

\section{Visual arts education and the education of vision}

Different forms of visual education take place in all school subjects. One just has to think of the highly abstract visualizations pupils have to be accustomed with in subjects like mathematics or geography to understand how the different representational practices of different areas of knowledge influence our perceptional abilities. In spite of these considerations, seeing and looking are often thought of as more important activities in the subject of visual arts than in the other school subjects. At least since Leonardo da Vinci's (1995) inquiries into the functions of human eyesight as the basis for painting, Western culture has seen the production of artistic artifacts as being intimately connected to the nature of visual perception. Because pictures are commonly thought of as direct visualizations of inner or outer worlds, vision is thought of as more fundamental in relation to the arts than to other visually-oriented symbol systems like letters, diagrams or maps. 
However a closer look at some of the most important $2 \mathrm{O}^{\text {th }}$ century Scandinavian textbooks provides some modifications to the presumed centrality of vision to visual arts education. As a matter of fact it seems that the discourses that have been central in the construction of visual arts education have rarely been specifically engaged with the education of vision. In visual arts, as in most other school subjects, it has been implied that seeing is a natural and unproblematic given, and even if there are big differences in the naturalized strategies of vision implicit in different discourses, these shifts have not been given particular attention. Only in very few cases have strategies of vision been discussed as particular relational forms which are acquired through specific social and educational practices.

As opposed to the subject of visual arts, in visual culture studies strategies of vision are looked upon as culturally, socially and historically contingent constructions. Following this line of thought in the following pages I will relate dominating visual strategies in Western modernity to selected historical discourses in art education. I have chosen to name the three different strategies of vision around which I will develop my inquiries: the camera obscura strategy, the subjective strategy, and the critical strategy.

\section{The camera obscura strategy of vision}

In 1913 the Norwegian art teacher Anna Holck wrote a groundbreaking book called Tegning efter gjenstande (Drawing from objects). In opposition to most drawing education at the time, Holck's position was that children should be taught how to draw through accurate observations of real objects taken from everyday life. They should not, as in the traditional drawing education, start out by drawing an infinite number of straight lines, curved lines and geometrical figures to train the movement of the hand, and they should not even be taught how to copy drawings from books which, according to Holck often provided false knowledge in respect to the real appearance of the objects. Holck believes that children should not be taught formally how to draw from objects until the age of $11 .^{2}$ Until then they should be left free to draw in their own naive way by making simple illustrations to themes selected by the teacher by which they can express their 'childish fantasies'.

The reasons Anna Holck gives for her introduction of the new methods were as revolutionary as the methods themsel- 
ves: instead of training the pupils to become skilled craftsmen, who could do correct workshop drawings, she wanted to train the pupils' accurateness of seeing to make them become seeing and thinking persons. She explained:

Not only in the drawing lessons do they have to be forced to see and think They have to bring these useful qualities with them in their lives - wherever they go. They have to learn to always keep their eyes about them and reflect about what they see and use their reflections. We know how many persons walk around like blind people in spite of their good eyesight. Dull and indifferent to everything they pass by. They never learn from life as it unfolds around them. (HOLCK, 1913, p. 4; translation by Tony Maxwell)

In this way Holck makes a unique and ambitious connection between drawing and seeing, seeing and reflection, and reflection and mental presence. An important goal of her drawing lessons became the improvement of students' general awareness and curiosity though the education of vision: "One, so to speak, adopts a researcher's eye, which is useful in all aspects of life". (HOLCK, 1913, p. 5)

The many instructions in the book about the correct positioning of the body and the hand and about the right techniques of observation and representation can be seen as practically-oriented descriptions and visualizations of the strategy of vision which Jonathan Crary (1990) calls the 'camera obscura model'. The pupils had to sit in a stiff upright position with their eyes focused on the object in front of them to be able to perceive and reproduce the object's correct proportions and perspectival position from a single and immobile point of view (Figure 1). Observation and representation were described as interconnected in a kind of quasi-mechanical process, similar to the function of the camera obscura ${ }^{3}$ where an image is produced inside a box without interference from any medium except the refraction of light rays through a small hole.

Crary offers further considerations about the significance of the camera obscura model by connecting it to a certain form of subjectivity:

[The camera obscura] indicates the appearance of a new model of subjectivity, the hegemony of a new subject-effect /.../ it necessarily defines an observer as isolated, enclosed, and autonomous. (CRARY, 1990, p. 38 f.) 


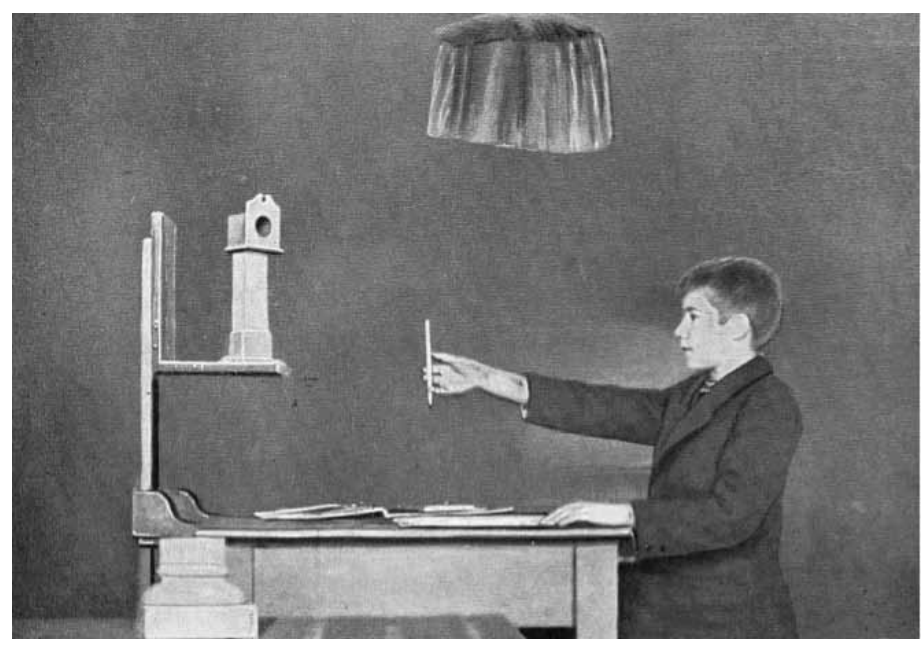

In this perspective the education of the seeing and thinking person constituted an important part in the education of the modern autonomous and reflective individual. The apparently neutral and controlled relationship between subject and object in Holck's drawing exercises contributed to the maintenance of a common understanding of how humans gain objective knowledge about the world. The camera obscura strategy of vision allowed no such thing as subjective emotions and desires to blur objective perception and representation. On the contrary this strategy remained unquestioned as the 'natural' one, precisely because it forced the mind (and the hand) to reproduce the world the way it objectively is.

\section{The subjective strategy of vision}

In the second part of his study Jonathan Crary describes how a shift in the dominant constructions of human vision towards more psychologically-orientated strategies of vision took place in leading European thinking around 1840. The positioning of knowledge as an active process located in the subject in Kant's philosophy, the studies in the perception of colors carried out by Goethe, and analyses of the senses by Schopenhauer all contributed to the appearance of

... a moment where the visible escapes from the timeless order of the camera obscura and becomes lodged in another apparatus, within the unstable physiology and temporality of the human body. (CRARY, 1990, p. 70).
Figure 1

"Position when you take sight" Illustration and caption reproduced from Holck (1913, p. 16) 
In the late $19^{\text {th }}$ and the $20^{\text {th }}$ centuries a range of alternative thoughts about the role of visuality in relation to knowledge were developed in both American and European philosophy. In his book Downcast eyes, the denigration of vision in twentieth-century French thought, the American scholar Martin Jay (1993) analyses "the anti-ocularcentric discourses of French thinkers from Bergson and Lacan to Derrida and Lyotard. His point is that although the $20^{\text {th }}$ century was a period in which the reproduction and diffusion of images became a naturalized part of everyday life in Western countries, this enormous amount of visual stimuli was not followed by an increased reliance on vision as the most important of the senses.

On the contrary, $20^{\text {th }}$ century thinking was marked by a growing suspicion that seeing and looking were reliable ways of getting knowledge about the world. Reality in these lines of thought was not there before our eyes to be grasped through careful observation, but was perceived through a blurred filter of inescapable feelings, instincts and desires. Modern philosophy, psychology and psychoanalysis introduced new ideas about vision which during the twentieth century contributed to the formation of alternative and powerful redescriptions of art education.

In Scandinavia what I define as oche subjective strategy of visions became an important element in the discursive construction of a new school subject called "creative arts" (Danish: formning) which substituted drawing in the years around 1960. One of the most influential books on the theory of creative arts education was Creative and mental growth, written by the Austrian-American professor Viktor Loewenfeld (1947). In this book Loewenfeld banned all forms of drawing from objects and introduced free creative expression as a foundational didactic principle in arts education. One of the reasons he gave for this shift was that children's expressions of visual experiences were naturally different from adults, and that it was to be considered in conflict with their psychological nature to teach them how to copy from reality:

Precisely from our analysis of this discrepancy between the representation and the thing represented do we gain insight into the child's real experience, Loewenfeld (1947, p. 2) stated, and he continued: "Therefore it is easy to understand that any correction by the teacher which refers to reality and not to the child's experience interferes greatly with the child's own expression". 


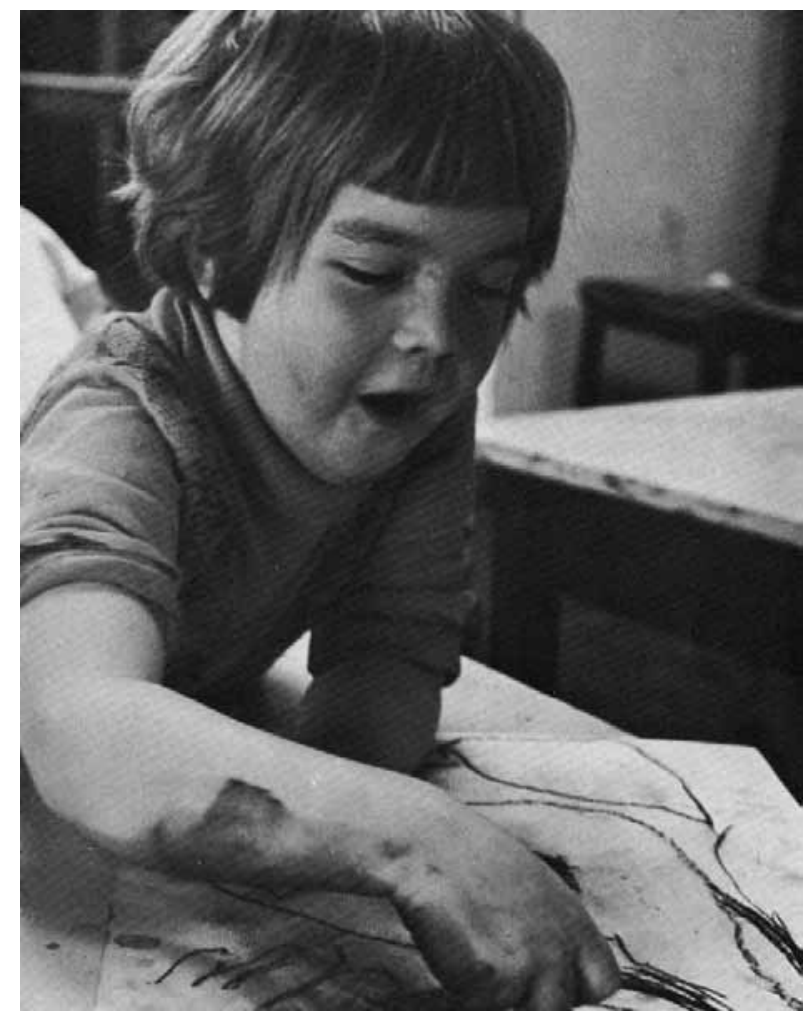

The educational goal of art education in Loewenfeld's words was mainly to be found in the idea of continuous personal growth towards success and happiness:

The child who has developed freedom and flexibility in his expressions will be able to face new situations without difficulties. Through his flexible approaches toward the expressions of his own ideas, he will not only face new situations properly but will adjust himself to them easily. The inhibited and restricted child, accustomed to imitating rather than expressing himself creatively, will prefer to go along set patterns in life. Since it is generally accepted that progress, success, and happiness in life depend greatly upon the ability to adjust to new situations, the importance of art education for personality growth and development can easily be recognized. (LOEWENFELD, 1947, p. 7)

The appreciation of subjective expression from within and the denigration of objective vision from without in the

\section{Figure 2}

"Children like to scribble and this activity provides them with great satisfaction" Illustration and caption reproduced from Lowenfeld $\mathcal{E}$ Brittain (1976, p.111) 
education of children contributed to an inversion of the educational goals of visual arts: In Hoick's discourse the most important goal of art education had been to teach the pupils how to mirror the world in an objective and reflective way in order to make them become autonomous and rational citizens according to generalized social standards. In Loewenfeld's discourse the most important goal was to teach the pupils how to express their subjective feelings and moods in order to make them become flexible individuals capable of personalized adjustments to ever-changing situations. ${ }^{4}$

By adopting subjective strategies of vision, the didactics of creative arts separated itself from objective forms of knowledge which became the domain of so-called scientific subjects. Instead it adhered to less appreciated artistic and subjective forms of knowledge of the so-called aesthetic subjects. The education of vision in Scandinavian art education became connected to the education of the soft human qualities of the natural and harmonious individual, capable of being faithful to the truth of his inner eyes.

\section{The critical strategy of vision}

Ten years after the introduction of the school subject of creative arts, a new order of discourse based on critical studies of the social impact of mass-produced images entered the Scandinavian field of art education. In 1970 two Swedish art educators, Gert Z. Nordström and Christer Romilson (1970), wrote a small but groundbreaking book named Bilden, skolan och samhället (The Picture, the School, and Society) where they argued that free creative expression had to be substituted by different means of education such as the analysis of mass-produced pictures and production of alternative forms of politically-oriented visual communication. Their key argument was that art education had to provide the pupils with a repertoire of critical techniques to qualify them both, to be able to decode the influence from the powerful visual messages of the mass media, and to make them conscious of their own position of being suppressed and enslaved by these messages:

The influence is a reality here and now, and it does not go away just because well-meaning art teachers decline to participate in it. Those who benefit from the capitalist social system are the same people who control the production of 


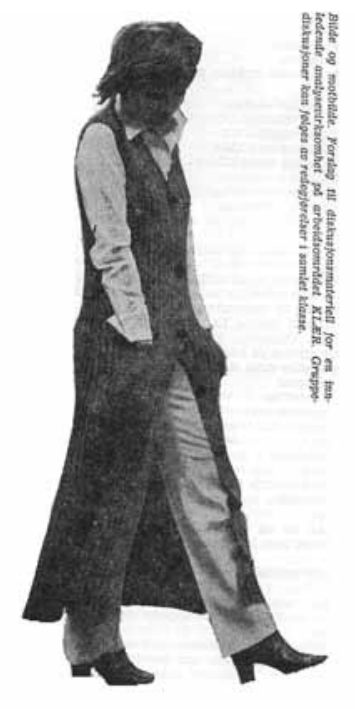

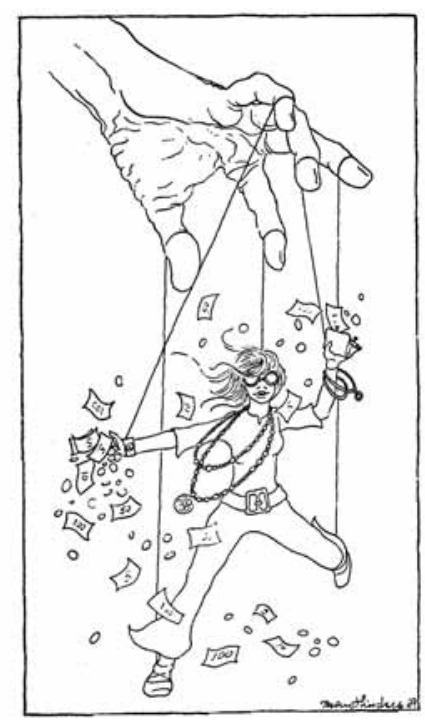

Figure 3

"Picture and counter-picture. Proposal for material for discussion aimed at an introductory activity in the work area CLOTHING. Group discussions can be followed by reviews in the classroom."

Illustration and caption reproduced from Romilson $\mathcal{E}$ Nordström (1970, pp. 105-106)

toys, the record companies and the newspapers and magazines. A large part of their propaganda apparatus consists of pictures. Advertisements, television series, films - all of these contribute to forming the individuals who are then expected to create purely on the basis of their unique selves when they practice painting in school. (NORDSTRÖM \& ROMILSON, 1970, p. 47; translation by Tony Maxwell)

To Romilson and Nordstrom both the camera obscura strategy and the psychological strategy of vision seemed hopelessly naive and without any critical potential. What pupils had in front of their eyes in their everyday lives were not home utensils to be faithfully taken in and copied as in Hoick's drawing exercises, but violent commercial pictures produced by the global companies of capitalist societies. And what pupils had in their minds was not some kind of fascinating imagery produced by their immature cognitive skills as Loewenfeld thought, but alienated, perverted visions and desires manipulated by powerful visual impressions which colonized their most intimate feelings.

Socialist art educators like Romilson and Nordström thought that new and critical strategies of vision had to be adopted, strategies which could help the pupils to understand how they were influenced and colonized by the mass-produced images of capitalist society. The critical strategy of vision implicit in their pedagogy was first and foremost a 
strategy of suspicion. Pupils had to be educated to question visual phenomena, as for example: Who has produced this image? Why has it been produced? What is the message? Is this message in accordance with my social interests or not? Only when the pupils had learned to unmask the hidden manipulative messages of the images of the media could they be allowed to make their own productions and try to construct visual images in accordance with their real and genuine interests as human beings. The educational goal implied in this strategy was emancipation and the raising of consciousness.

The critical strategy of vision in art education has many points in common with both epistemological and experimentalist approaches to visual culture studies. It is a strategy which thinks that vision is somehow socially constructed, it is a strategy which asks critical questions about visual experiences in relation to questions of power, and it is a strategy which tries to experiment with the construction of alternative visual experiences by producing alternative forms of visual communication. The main difference between the analytic strategies in visual culture studies and those of critical art education is that the latter does not escape a classical modernist ontology: that behind all the artificial influences and constructions of capitalist society lies some kind of natural realm of authenticity - some place where vision is not constructed but immediate, and a world were critical inquiries will be useless because everything will appear to be exactly as it is according to what was thought to be foundational human interests.

\section{Conclusion}

The dominant strategies of vision in Scandinavian art education are all inscribed in broader epistemological assumptions of Western modernity. The fundamental idea is that, in spite of denigrations of vision, it should somehow be possible to see and depict the world as it really is: (1) objectively through the camera obscura strategy, (2) according to what is actively in your mind through the subjective strategy, or (3) as an expression of true human interests through the critical strategy. These three strategies have somehow remained naturalized and unquestioned in discourses on visual arts education at least until the 1990s, and this naturalization has turned them into instruments of power - teaching students about right and wrong strategies of looking and representing. 
Inspired by the epistemological approaches to the history of vision by Jonathan Crary (1990) and Martin Jay (1993) I have tried to redescribe the educations of vision implied in Scandinavian art education as social constructions which serve certain educational goals. I do not think that it is possible to escape these constructions by some regressive movement back to nature, to childhood, or to authenticity. What teachers can do is to try to avoid totalizing one of them in a singular construction of power. Using epistemological approaches to reflect on strategies of vision in education, I think we can use these strategies in more shifting, attentive and careful ways and thereby maybe avoid some of their implicit tendency to marginalize difference.

\section{Part II: Experimental redescriptions}

In this part of the article, I present some redescriptions of visual relationships which might serve as tools in the construction of alternative forms of educations of vision. For this purpose, I discuss some of the approaches to visual culture studies that I call experimentalist. In my understanding, the main differences between epistemological and experimentalist approaches to visual culture are not about basic assumptions, but rather about different focal points. While epistemological inquiries like those of Jonathan Crary and Martin Jay focus on how the historical and social construction of dominant modern strategies of vision has occurred, experimentalist approaches attempt to challenge the hegemony of these visual strategies through the production of new vocabularies, alternative connections and different narratives. In this sense experimentalist approaches are very much in line with the central ideas of the neo-pragmatist philosopher Richard Rorty ${ }^{5}$ who thinks that philosophy should be committed to the construction of practically-oriented redescriptions, inspired by art and literature, rather than to the search for true or representative knowledge. (RORTY, 1989; 1999)

Working mainly along the lines of poststructuralist and feminist thinking, researchers in visual culture like Irit Rogoff, Mieke Bal and Norman Bryson construct experimentalist redescriptions where difference is thought of as a constituent component of strategies of vision. To exemplify how difference can be understood in visual culture studies, Irit Rogoff quotes the feminist scholar Donna Haraway (quoted by Rogoff 2000, p. 25), who argues: 
... for politics and epistemologies of location, position ${ }^{i}$ ng and situating, where partiality and not universality is the condition of being heard to make rational knowledge claims. These are claims on people's lives: the view from the body, always a complex, contradictory, structuring and structured body versus the view from above, from nowhere, from simplicity.

From an educational point of view, I think that both epistemological and experimentalist approaches to visual culture have important qualities which cannot be excluded. I will return to this discussion in the last part of the article. First I will introduce two terms which I find important as possible tools in the development of alternative strategies of vision: the term visual event which is inspired by an article by Mieke Bal and Norman Bryson (1991), and the concept of the curious eye which has been introduced by Irit Rogoff.

\section{First redescription: Visual events}

In traditional academic disciplines like art history and aesthetics, subjects (viewers), objects (things which are looked at), representations (images and pictures) and vision (eyesight) are considered as separate elements which can be studied each in their own right. For example one could say that art history is mainly about the study of pictures, aesthetics ${ }^{6}$ is mainly about the study of viewer's response to art, and eyesight is studied primarily in terms of physiology and physics.

In their important article Semiotics and Art History (BRYSON \& BAL, 1991) Norman Bryson, professor of history and art theory, and Mieke Bal, professor of theory of literature, use a poststructuralist semiotic perspective to challenge and make contributions to the discipline of art history. In their analyses they use categories taken from the theory of communication ${ }^{7}$ together with the founding semiotic theories of Charles Sanders Pierce, Ferdinand de Saussure, and Jacques Lacan. Furthermore they make their investigations from a poststructuralist and deconstructivist perspective mainly inspired by the writings of Jacques Derrida and James Culler, showing how processes of ongoing semiosis ${ }^{8}$ and continuous displacement destabilizes the idea of fixed categories in the field of vision. Bal and Bryson (1991, p. 194; italics in original) use the term event to produce redescriptions of the sign as inscribed in socially situated processes of semiosis: 


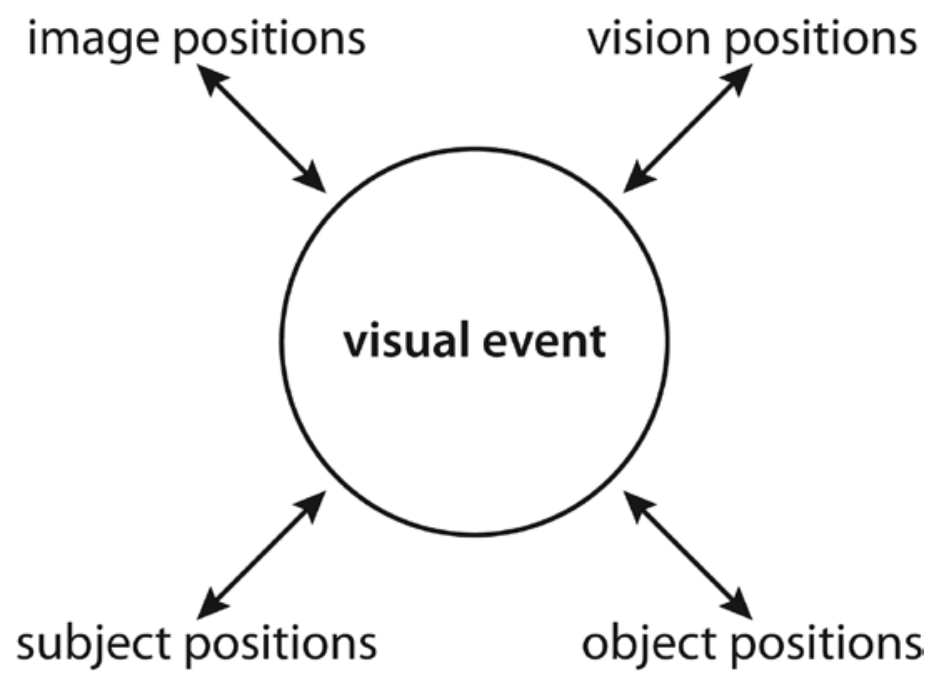

To think of semiosis as a process and as a movement is to conceive the sign not as a thing but as an event, the issue being not to delimit the sign from other signs, but to trace the possible emergence of the sign in a concrete situation, as an event in the world.

Inspired by Bal and Bryson's article, I have introduced the term visual event to the Danish field of visual arts education. ${ }^{9}$ I use the term to challenge more traditional categories, stressing the fact that subjects, objects, representations etc. can be redescribed as positions which contribute to complex reciprocal and relational processes. The object position, the image position, the subject position, and the vision position are all possible names for the most important positions which are involved in visual events (Figure 4 ). The choice of the word 'positions', indicates that these are not necessarily connected to traditional understandings or particular objects or persons, but can be occupied in different ways. For example a person (a physically present human being) can occupy all of the different positions: she or he can be positioned as a viewer in the subject position, as a thing to be looked at in the object position, as a representation in the image position, and as adopting a particular way of looking at things in the vision position. The same thing counts for an image: to take the most unusual aspect I think it is possible for e.g. a photograph or a painting to occupy a vision position in a visual event. As explored by theorists like Roland Barthes (1983) and Jacques
Figure 4

Model of the visual event 
Lacan (1994, $91 \mathrm{ff}$.) it is in fact possible to experience pictures or even objects looking back at you with a sort of gaze that makes the observed person experience her or himself as an object in the visual event and not as a subject.

The practically oriented importance of the introduction of the term visual events in redescriptions of educations of vision in my opinion lies in the possibility of creating more playful visual relationships than usually allowed in traditional subject-object relationships. Thinking of visual events as open situations made up by nomadic and shifting positionalities where in theory anything can happen, helps us a little step along the way to challenging classical Western strategies of vision. The next redescription I think will take us in the same direction by using a different and more personal point of departure.

\section{Second redescription: The curious eye}

Irit Rogoff, professor of art history and visual culture, often refers to herself as a culturally displaced person (e.g. ROGOFF, 1998; 2000). Born in Israel, but having lived and worked in many different countries, and speaking several languages, she feels an obligation to try to write the complicated problematics of her different cultural positions across one another to see what kind of insights can be produced from such mixtures. In her projects she consciously uses her own experience of cross-cultural positions to explore different forms of positionalities which can be related to questions of vision and visual culture. Rogoff also deals with the radical learning processes that are involved when one has to move between different and conflicting cultural paradigms. Experiences of loss and reconstruction become the focal points in these transitional processes which Rogoff reads as necessary points of departure for the construction of effective experimentalist redescriptions:

The moment in which loss is clearly marked and articulated is aim the moment in which something else, as yet unnamed, has come into being. Learning and transitional processes are not so much the addition of information as they are the active processes of unlearning which need to be carefully plotted out into active theories of unlearning which can be translated into active positions of unbelonging. (ROGOFF, 2000, p. 3)

By attempting the construction of active positions of unbelonging as theoretical tools, Rogoff posits effective challen- 
ges to essentialist concepts such as origin, basis and identity. In her books and articles she persistently directs her interest towards dislocated and mixed positionalities, using her own nomadic experiences to create forms of inquiry which escape fixed intellectual positions.

One model which Rogoff has tried to develop as a tool for experimentalist redescriptions of strategies of vision, is the strategy of the curious eye. In contrast with the good eye of connoiseurship, the curious eye is a strategy of vision which relates to visual events in a way which is direct, personal, partial and curious. It is not an objectifying gaze but a form of looking that participates as a part of the event itself:

Curiosity implies a certain unsettling; a notion of things outside the realm of the known, of things not yet quite understood or articulated; the pleasures of the forbidden or the hidden or the unthought; the optimism of finding out one had not known or been able to conceive before. (ROGOFF, 1998, p. 18)

I understand the curious eye as a way of establishing visual relationships which accepts and uses the shifting positionalities in the creation of visual events. To give an example of my understanding taken from everyday life in school, I have often noticed how many pupils prefer to create relationships with objects and images through the construction of spontaneous narratives from their everyday lives. When for example a pupil chooses to relate to a visual event which makes her think of a cat, she might start with some long and detailed ongoing talk about a cat she has at home (or in one of her homes). She might tell stories about her cat, which seem completely irrelevant to the situation, and she might stop looking at the object, using bodily movements to show the other pupils how the cat walks or eats or showing what the home looks like. In this way she spontaneously creates a new visual event by using her memories and associations in her communication with the group.

However, according to my experience, when constructing these forms of associative and unfocused narratives and performances, pupils are often stopped quite abruptly by their teachers. The pupils are interrupted because the teachers think that they should stick to more correct art-like discussions about the formal and thematic qualities of e.g. a picture or possibly about their deeply felt emotional responses to it. In my opinion by interrupting continuously in this way the teachers reinforce a modernist tradition which encourages 
classical subject-object strategies of vision at the expense of more experimentalist approaches.

As an alternative, in the example described above, the teacher could make the choice not to interrupt the student, but to ask her to explore her experience even further in an experimental production of a new visual event. Seeing the strategy of the curious eye as a possibility for the experimentation with shifting individual positions, I think would make it possible for teachers to conceive of memories and associations, small-talk and gossip, silence, shouting and bodily movement etc. as forms of relationship, which are as interesting in an educational context as more traditional approaches like observation, expression of personal feelings or analysis. I do not think that any form of object or image requires fixed forms of relationships, even if the framing, for example an art exhibition, might suggest this. Using the concept of the curious eye and inspired by pragmatist philosophy, I would rather see objects and images as practically-oriented positions made not to be understood, but to be used in the creation and exploration of visual events.

As Rogoff points out very clearly, talking about difference or about positions of unbelonging is talking about the actual conditions of life $\mathrm{e}^{\mathrm{1}}$. In today's Western societies one does not have to be an immigrant to conceive of oneself as a traveler. As social theorists like Zygmunt Bauman and Homi K. Babha have discussed extensively ${ }^{11}$, all of us to some extent take part in nomadic forms of life by relating to an increasing number of shifting discourses. This construction of reality, I think, makes the privilege of traditional strategies of vision problematic. In a perspective of difference we cannot allow ourselves to give unconditioned privilege to certain strategies of vision in education that have been constructed in a particular tradition of Western enlightenment, and which are based on ideas of control and objectification. By accepting and exploring the curious eye in experimentalist redescriptions we can start to construct educations of vision which accept the complexity of the fragmented, the partial, and the composed.

\section{Part III: Educations of vision in late modernity}

One of the things which characterize late modernity ${ }^{12}$ is the continuous tension between dominant systems of thought and the increasing need for the acceptance and exploration of individual and cultural differences. In this social con- 
dition late modern educational systems have to fulfill two opposite functions: to socialize the students by giving them access to and knowledge about existing systems of thought and practices in the dominant culture, and to open up for difference by accepting and challenging the student's needs for shifting and diversified forms of self understanding and self creation. In this final part of my article I will briefly discuss two different but overlapping forms of education of vision: one that uses knowledge produced by epistemological inquiries as sources of inspiration for educational processes of socialization ${ }^{13}$, and one that uses strategies produced by experimentalist redescriptions as sources of inspiration for educational processes of self creation ${ }^{14}$.

\section{Socialization}

As discussed in the first part of this article, educations of vision take place in different areas of knowledge and therefore are to be considered as an important part of all school subjects. Epistemological inquiries into traditional modernist strategies of vision like those of Jonathan Crary (1990) and Martin Jay (1993) have offered some necessary platforms of knowledge to give us insight into the social construction of dominant strategies of vision. But what are the educational reasons for teaching students about dominant (and possibly oppressive) strategies of vision?

From a traditional point of view the most important reason for having schools is the institutionalized and controlled socialization of children and young people to familiarize them with the dominant traditions and most recognized knowledge of the society in which they will operate. In different periods of the history of schools, focus has been put on shifting aspects of this socialization, e.g. acquisition of factual knowledge, personal growth, awareness of history and traditions and good manners. In late modern educational thinking the idealistic motives of earlier educational thinkers have largely been substituted with more pragmatic approaches. Following this line of thought I will argue that the reason why we should continue to teach pupils about the dominant strategies of vision is that only by being very confident with these strategies and the way they work, will the pupils have the choice to act correctly in their relationships within the dominant culture.

It is a well-known fact that although many different cultures, social classes, family forms etc. exist side by side in contem- 
porary Western societies, the children who are most confident with the dominant culture perform better both in school and in their future lives. As pointed out persistently by the French sociologist Pierre Bourdieu (e.g. 1997), if the educational system does not take on the task of socialization in relation to the dominant cultural strategies and codes seriously, many children will probably never understand the more subtle standards of right and wrong, and will thereby risk being denied access to large areas of society ${ }^{15}$.

In relation to the school subject of visual arts, the educational goal of socialization means that art teachers at all levels of study have an obligation to make their students confident with traditional strategies of vision of the field such as the camera obscura strategy, the subjective strategy and the critical strategy. By using meta reflective approaches to art education, students should learn to question these strategies e.g. by asking: Where do they come from? How do they function? And how can they be used? Furthermore they should experiment with the use and the limits of dominant strategies of vision in the experience and creation of visual events. As discussed in my earlier example, small-talk about your cat at home, gossip, shouting and bodily movement are all generally considered to be wrong according to these strategies, while careful observation, expression of personal emotions and critical analysis are considered to be right. Even if teachers do not agree with the dominant definitions of right and wrong, in my opinion we nevertheless have an obligation to show to our students very explicitly how traditional visual strategies work. Only by knowing which standards they are up against, can students engage in the exploration of other more experimental strategies in fruitful ways.

\section{Self creation}

When it comes to the other side of visual education, openness towards difference and self creation, I find experimentalist redescriptions in visual culture studies to be very useful. In late modernity most individuals live under shifting conditions which involve polycentrism, cultural nomadism and experimental risk-taking. Furthermore new patterns of vision are introduced to us through our daily experiences with new visual media, new communication systems, new representational schemes and new forms of spatial organization. Recent investigations (e.g. DROTNER, 1995) have shown that chil- 
dren and young people are among the keenest users of new media, and they are therefore likely to be among the first to explore and incorporate different strategies of vision. From this perspective, I think that the socialization of students according to traditional modernist standards, as described in the previous paragraph, should be supplemented by invitations to the students to experiment with different strategies of vision as a necessary part of educational processes of self creation.

Experimentalist redescriptions in visual culture have worked to introduce understandings of visual events as dramatic and creative activities. In relation to visual experiences they have proposed to give up the ideal of the focused, concentrated, autonomous and powerful observer, to experimentally explore positions and strategies of unbelonging, decentering, dissemination and polycentricity. I think that visual education can open up to the creation of new positionalities which operate with difference in positive ways by staging and relating to visual events in experimental and playful ways e.g. inspired by computer games, television programs, cartography, contemporary art, and dance.

When it comes to art education, I believe that students of visual arts should be offered possibilities to explore the forms of visual imagery they prefer, and that they should be invited to experiment with their relationships to this imagery through the production of new visual events. Strategies of curiosity towards contemporary visual culture should supplement the suspicious eye of traditional criticism, and playful, collective approaches to picture production should supplement the modernist demands of serious, strongly individualized production of art works. Instead of coping with the representation of traditional realities such as real objects, real emotions or real social interests, art education could also be about coping with the alternative realities of fiction. And instead of sitting or standing in front of objects to be produced or looked at by a controlling subject, art education could be about the bodily and sensuous participation in visual events by involving the whole environment and including experiences of sound, smell, touch and movement.

Individual experiences like those of culture, class, family and gender are deeply visually and sensuously embedded, and teachers of all school subjects should be aware of how to work actively with these aspects to help students from all positions within society in their processes of self creation. In contrast to the objectifying strategies of vision, which in mo- 
dern Western societies are necessarily involved in the processes of socialization, processes of self creation should be about the exploration and creation of alternative strategies of vision embedded in a perspective of difference.

\section{Conclusion}

In this article it has not been my intention to give direct instructions to teachers, but rather to introduce visual culture studies as a fruitful theoretical approach in relation to education in late modernity. Nevertheless it seems that important and interesting experiments are being carried out in some schools and other educational institutions. If once again we take the field of Scandinavian art education as an example, there is a growing awareness in the direction of the need to socialize students through the use of shifting methodological and analytical approaches to the dominant strategies of vision. ${ }^{16}$ When it comes to experimentalist approaches, I know that interesting staging's of visual events are made in Danish schools and teacher training colleges, especially in relation to the teaching of contemporary art forms. ${ }^{17}$ In some cases the students are encouraged to explore issues of difference, for example through the staging of narratives from their everyday lives or through the appropriation of visual fragments from their preferred television programs or computer games. A group of teacher trainers are even experimenting with staging visual productions where students adopt second order skills. ${ }^{18}$ In these experiments strategies of quoting, copying, sampling and simulating are used as a basis for the production of new visual events which open possibilities for working actively with positioning, curiosity, difference and self creation in art education.

In spite of such important initiatives, I think that there is a general need in Scandinavian art education for an introduction of more advanced strategies of reflection. The use of shifting strategies of vision in relation to different forms of art production is often reduced to unreflected stereotyped assumptions, e.g. when the subjective strategy of vision is introduced as the only possible approach in the production of expressive art- like products such as paintings or sculptures (ARVEDSEN, 200o). When it comes to the teaching of experimentalist approaches, in my field studies (e.g. ILLERIS, 1999a; 200o) I have sometimes observed students being stopped half way in their experiments with visual events because their approaches do not seem serious or authentic enough according 
to the ideals of the teacher. In this way the teacher employs dominant strategies of vision to marginalize alternative approaches without the necessary reflexive distance.

\section{Leaving the specific field of art education}

I think that visual culture studies offers a qualified point of departure for the introduction of constructivist and pragmatist perspectives on educations of vision in all subjects. From these perspectives traditional modernist strategies of vision and representation, and experimentalist approaches should both be introduced to students as choices. ${ }^{19}$ However the aim of these approaches is not to try to turn students into total relativists. On the contrary they should help teachers and students in the construction of educational spaces were personal and cultural convictions and preferences can be displayed and exchanged and new possible perspectives can be staged.

In educations of vision, as in other forms of education, the delicate democratic balance is on one hand to try to respect individual convictions but on the other hand to question all fundamentalisms. In my opinion if ways of seeing, as shown by visual culture studies, are largely dependent on social constructions, teachers have a democratic obligation to try to teach students about them as such. Furthermore there is an important educational task in demonstrating how strategies of vision relate to issues of power by making students aware of how some strategies are more accepted and dominant than others. What in my opinion is not acceptable when we talk about educations of vision, is to ignore difference by making the unreflected claim that we all see things the same ways.

\section{References}

ARVEDSEN, K. (2000). Kan man udtrykke sig uden at kommunikere? Kan man kommunikere? uden at udtrykke sig? Om begreberne 'personligt udtryk', 'meddeleIse' og 'visuel kommunikation'. Billedpcedagogisk tidsskrift, 4(2), 17-21.

BAL, M. \& BRYSON, N. (1991). Semiotics and Art History. The Art Bulletin, 78(2), 174-208.

BARTHES, R. (1983). Det lyse kammer. Bemcerkninger om fotografiet. København: Rcevens sorte bibliotek.

BHABHA, H.K. (1997). Culture's in-between. In Hall, S. \& du Gay, P (eds.): Questions of cultural identity. London: Sage. 
BAUMAN, Z. (1997). From pilgrim to tourist — or a short history of identity. In Hall, S. \& du Gay, P. (eds.): Questions of cultural identity. London: Sage.

BOURDIEU, P. (1997). Af praktiske grunde. Omkring teorien om menneskelig handlen. København: Hans Reizels Forlag.

BOURDIEU, P. \& Darbel, A. (1991). The Love of Art. Cambridge: Polity Press.

BUHL, M.; Christensen, K. Meisner \& Skov, K. (2003). Praktik - set i lyset af billedkunstfaget. København: N. Zahles Seminarium.

CRARY, J. (1990). Techniques of the Observer.Cambridge, Mass.: MIT Press.

DA VINCI, L. (1995): Trattato della pittura. Milano: TEA.

DROTNER, K. (1995). Mediedannelse: bro eller barriere? Om børns og unges mediebrug. København: Statsministeriets Medieudvalg.

FLENSBORG, I. (1994). Rumopfattelser 'i børns' billeder. København: Danmarks Lærerhøjskole.

FOSTER, H. (ed.) (1988). Vision and visuality. New York: The New Press.

GERGEN, K. J. (1999). An Invitation to Social Construction. London: Sage.

GIDDENS, A. (1991). Modernity and Identity. Self and Society in the Late Modern Age. Cambridge: Polity Press.

HOLCK, A. (1913). Tegning efter gjenstande. Haandbok for lerere og elever. Kristiania: Aschehoug \& Co.

ILLERIS, H. (1999a). Kyklop Kamé- en kulturhistorisk analyse af de kulturelle koder fire 14-15 årige valgfagselever anvendte ved omtalen af et samtidskunstvcerk. (Billedpædagogiske Studier bd. 3) København: Danmarks Lærerhøjskole.

ILLERIS, H. (1999b). At opleve et kunstværk - kan det læres? Didaktiske overvejelser med udgangspunkt i 'kunstpædagogikkens dilemma'. Forskningstidsskrift fra Danmarks Lærerhøjskole, 4(3), 11-38.

ILLERIS, H. (2000). Copying - You Just aren't Supposed to do That! In Lindström, L. (ed.): The Cultural Context. Comparative Studies of Art Education and Children's Drawings. Stockholm: Stockholm Institute of Education Press.

ILLERIS, H. (2002a). Billede, predagogik og magt. Postmoderne optikker i det billedpcedagogiske felt. Frederiksberg: Samfundslitteratur.

ILLERIS, H. (ed.) (2002b). Studies in Visual Arts Education. København: The Danish University of Education.

JAY, M. (1993). Downcast Eyes. The Denigration of Vision in 
“Twentieth-Century French Thought. Berkeley: University of California Press.

KÖHLER, R. \& PEDERSEN, K. (1978). Barns billeder i en billedkultur. Bredsten: Ulrika.

LACAN, J. (1994) The Four Fundamental Concepts of Psycho-Analysis, London: Penguin Books.

LINDSTRÖM, L. (ed.) (1998). Nordic Visual Arts Research. A Theoretical and Methodological Review (Stockholm Library of Curriculum Studies 2) Stockholm: Stockholm Institute of Education Press.

LOEWENFELD, V. (1947). Creative and Mental Growth. New York: The Macmillan Company.

LOWENFELD, V. \& Brittain, L.B. (1976). Kreativitet og veekst, and edition. Copenhagen: Gjellerup

MITCHELL, W.J.T. (2002): Showing seeing. A Critique of Visual Culture. In Holly, M.A. \& Moxey, K. (eds.): Art History, Aesthetics, Visual Studies, New Haven: Yale University Press.

NORDSTRÖM, G.Z. \& ROMILSON, C. (1970). Bilden, skolan och samhället, Stockholm: Aldus/Bonniers.

PEDERSEN, K. (1999). Bo's Billedbog — en drengs billedmcessige socialisation. København: Dansk psykologisk Forlag.

ROGOFF, I. (1998). Studying Visual Culture. In Mirzoeff, N. (ed.): The Visual Culture Reader. London: Routledge.

ROGOFF, I. (2000). Terra Infirma. Geography's visual culture. London: Routledge.

ROGOFF, I. (2003). Gossip as Testimony. A Postmodern Signature. In Jones, A. (ed.): The Feminist Visual Culture Reader. London: Routledge

RORTY, R. (1989). Contingency, irony and solidarity. Cambridge: Cambridge University Press.

RORTY, R. (1999). Philosophy and social hope. London: Penguin Books.

WALKER, J.A. \& CHAPLIN, S. (1997). Visual Culture: An Introduction. Manchester: Manchester University Press.

\section{NOTES}

1. According to the current terminology of visual culture studies, vision refers to the physical and physiological process of seeing, while visuality refers to the social processes that are always involved in seeing. However this distinction is not always as simple as it might seem. In the words of Hal Foster (1988, p. ix): "Although vision suggests sight as a physical operation, and visuality sight as a social fact, the two are not opposed as nature to culture: vision is social and historical too, and visuality involves the body and the psyche. For a further elaboration on the terminology of visual culture see e.g. Walker and Chaplin (1997). 
2. Holck believes that drawing as a separate school subject should only be introduced in the fifth year of school. Before that, drawing education should be thought of as a natural part of so called visual instruction (Norwegian: anskuelsesundervisning; HOLCK, 1913, p. 3). In visual instruction the younger school children (approx. 7-10 years old) were taught about different themes from national history, everyday culture, geography, nature etc. by observing and learning from the so called illustrative pictures (Norwegian: anskuelsesbilleder) hung in the classroom and drawings by the teacher on the blackboard.

3. The camera obscura is a closed box with a small hole in one of its sides. When the light from the exterior passes through the hole, an inverted image of what is outside the box in front of the hole will appear in the box on the wall opposite the hole.

4. In Loewenfeld's book the main focus is on the psychological development of children aged 2 to 11 . Loewenfeld (1947, p. 10o) believes that when children are 11 years old their drawings naturally reach the so-called pseudo realistic stages, which means that the child now makes her or his first attempts to observe visually. In this sense Loewenfeld basically agrees with Anna Holck that only by the age of 11 is the child mentally prepared to draw in a realistic way, which even in Loewenfeld's discourse appears to be the inevitable and right way for adults. While Holck's discourse focuses on how to teach children from 11 and up to do correct realistic drawings, Loewenfeld is mainly fascinated by the natural expressions of smaller children. However, both Holck and Loewenfeld in their texts consolidate the distinction between those who are able to perceive the world correctly through perspectivalist perception and reproduction, and the other ones - children (but even «insane» people and "primitive» people from other cultures) - who are naturally different and who had to be protected from the demands of objective vision. As a consequence of the shift in focus from the correct drawings of the older children to the expressions of the smaller children, the subject of creative arts in Denmark was limited to the earlier classes. Reminiscent of Loewenfeld's ideas, even today visual arts are taught only in years 1-5 of school. In the 1980 os and 1990s the Danish researchers Ingelise Flensborg, Kristian Pedersen and Rolf Kohler have convincingly demonstrated (1) that smaller children's drawings are not naive but are following other models of perception than the perspectivalist one (FLENSBORG, 1994), and (2) that children's pictorial languages are dependent on models of expression and motives that they meet in images and pictures from their everyday lives (KOHLER \& PEDERSEN, 1978; PEDERSEN, 1999). In this perspective the realist way of drawing does not seem to be any more natural to children from 11 and up than drawing from polycentric viewpoints or copying from cartoons and advertisements (ILLERIS, 2000).

5. In fact I have borrowed the term redescriptions from Richard Rorty's vocabulary. In line with central ideas of American pragmatism, Rorty argues that philosophy should have as its most important goal not to be true, but to be useful. To him the aim of all forms of knowledge production lies in the creative construction of examples and models which can serve the development of less cruel worlds for humans. In his opinion, so called imaginative narratives have a greater ability than so called scientific narratives to produce new vocabularies which can be used to challenge the hegemonies of traditional Western thinking and its claims of representational truthfulness.

6. In a recent article Mitchell (2002, p. 233) tries to define the disciplines of art history and aesthetics in their most expansive manifestations. In this perspective he characterizes art history as a general iconology or hermeneutics of visual images” and aesthetics as "the study of sensation and perception”.

7. The concepts Bal and Bryson (1991) take from communication theory are context, senders, and receivers. They use these words as headlines for the first three paragraphs of their article. 
8. The expression ongoing semiosis indicates the process where signs endlessly generate new signs without ever getting back to, or touching upon, the reality behind signs. Poststructuralist thinkers in fact think that our reality as human beings is made up by signs, and that therefore we have no access to a reality outside representation. Following this line of thought, Bal and Bryson (1991, p. 174) start their article by declaring that: "The basic tenet of semiotics, the theory of signs and sign-use, is antirealist. Human culture is made up of signs, each of which stands for something other than itself, and the people inhabiting culture busy themselves making sense of those signs".

9. See Chapter 5 in Illeris (2002a).

10. Rogoff (2003) discusses gossip as a form of postmodern inquiry. In her article in this journal Ingelise Flensborg discusses how bodily movement influences visual perception (see also FLENSBORG, 1994).

11. For shorter articles by these authors on questions of nomadic life forms and cultural identity see Bauman (1997) and Bhabha (1997).

12. I use the term late modernity to refer to the present organization and understanding of reality in Western societies. Other terms such as postmodernity, reflexive modernity or hypercomplexity have been used by sociologists to indicate particular aspects of late modern societies. I have borrowed the term late modernity from Anthony Giddens (1991), who argues against the idea that from the last decades of the $2 \mathrm{O}^{\text {th }}$ century we should be living in a postmodern age were a profound rupture with more classical forms of modernity of the $19^{\text {th }}$ and early $\mathbf{2 0}^{\text {th }}$ century has taken place. Giddens rather thinks that actual world views and organizational forms of Western societies can be described as a late phase in the development of those of the modern age.

13. The distinction between socialization and self creation is borrowed from Richard Rorty (1999, p. 114 ff.) where he introduces the term self creation as a parallel to individualization. I prefer the term self creation to individualization because self creation is clearly in accordance with the constructionist thesis, with which I agree. According to this thesis the concept of selves is largely a result of socially constructed narratives (see GERGEN, 1999, ILLERIS, 2002a). In his article Rorty argues that that the educational goal of socialization belongs to pre-college schools while the goals of individualization and self creation belong to colleges. I cannot agree with such a rigid distinction, as I think that the two processes can be distinguished analytically but are mostly intertwined in educational practice.

14. Rorty understands the term socialization in a more narrow sense than I do. To him socialization is basically about the acquisition of pre-established knowledge, while I also understand it as the acquisition of broader patterns of behavior.

15. To take an example from the field of fine arts Pierre Bourdieu and Alain Darbel (1991) have carried out a study on visitors in art museums that show that most people, and especially those from other cultures and social classes than the dominant ones, feel uncomfortable in art museums because they do not now the right ways to move about and how to look at the works of art. This means that most people are denied access to art museums because of the subtle standards of behavior and knowledge which are related to these places. Therefore one important task of visual arts education in school could be to teach the pupils about dominant standards of behavior, knowledge and strategies of vision belonging to the art museum, before (or together with) reaching about alternative approaches. For a discussion of Bourdieu's and Darbel's book in an educational perspective see Illeris (1999b).

16. As mentioned in the first part of this article, critical and analytical approaches have been introduced to Scandinavian art education in the 1970 and 1980s through the writings and practices of e.g. the Swedish art educators Gert Z. Nordström and Christer Romilson (1970) and the Danish art educators Rolf 
Kohler and Kristian Pedersen (1978). In the 1990s attempts have been made to differentiate and supply these theories, both by the authors themselves and by an increasing number of researchers in the field (for a view of Nordic approaches from the 1990 os see LINDSTRÖM, 1998). For a genealogical approach to Scandinavian art education see Illeris (2002a, b). The critical and analytical approaches are to some extent reflected in the latest ministerial programs in Scandinavian art education, where a variation of approaches to the subject is presented. However it seems that many art teachers have a tendency to continue old practices by favoring unreflected forms of free creative expression among the children.

17. In 2001 I worked in a teacher training college in Copenhagen. Here interesting approaches to contemporary art forms were carried out by some of my colleagues and myself.

18. For a definition of second order skills, see Mie Buhl's article. Together with two teacher trainers, Buhl is working on a research project that involves the use of second order skills in the training of art teachers (BUHL, CHRISTENSEN, MEISNER \& SKOV, 2003).

19. In her article Mie Buhl reaches many conclusions which are similar to mine: Her understanding of visual culture as a trans-disciplinay strategy of reflection of second orders is similar to my understanding of visual culture as a redescription of strategies of vision as culturally, socially and historically contingent constructions. Furthermore Buhl's understanding of pictorial production as dealing with options, as presentations and as the investigation of rules and their origins is also a basic perspective for working both with epistemological inquiries for the socialization of students in relation to dominant strategies of vision and for working with epistemological redescriptions and self creation.

Recebido em: 02/03/12

Aceito em: 09/01/13 


\section{HELENE ILLERIS}

helene.illeris@uia.no

Doutora em Arte/Educação atua na University of Agder e no Telemark University College, Noruega. Seus interesses de pesquisa incluem arte/ educação em escolas e museus com foco em cultura visual, formas artísticas contemporâneas, processos de aprendizagem estética, inclusão social e sustentabilidade. Em 2009 publicou dois livros com outros pesquisadores: Cultura Visual - Conhecimento, Vida, Política e Arte como Recurso para Aprendizagem. Tem artigos publicados em inglês, dinamarquês, sueco e italiano. É líder da rede nórdica de pesquisa Contemporary Art and Visual Culture in Education, e membro do Conselho de Artes da Noruega. 